\title{
Formulasi Serum Antioksidan Kombinasi Ekstrak Buah Ceremai Dan Kulit Buah Semangka
}

\author{
Eneng Elda Ernawati*, Yunahara Farida, Shelly Taurhesia \\ Fakultas Farmasi, Universitas Pancasila. Jl. Srengseng sawah, Jagakarsa, Jakarta, Indonesia \\ *Email : eldaernawati090291@gmail.com \\ (Submit 11/10/2021, Revisi 01/11/2021, Diterima 26/11/2021, Terbit 10/12/2021)
}

\begin{abstract}
Abstrak
Buah ceremai (Phyllantus acidus) mengandung, kuarcetin, mirisetin, pylantusol $A$, pylantusol B, asam sitrat, asam askorbat dan asam galat, sedangkan kulit buah semangka (Citrullus lanatus) mengandung retinol, tiamin, niacin, dan asam askorbat. Keduanya mengandung senyawa yang memiliki aktivitas antioksidan. Tujuan penelitian ini adalah membuat formula serum wajah dari kombinasi ekstrak buah ceremai dan kulit buah semangka serta menguji aktivitas antioksidannya. Buah ceremai dan kulit buah semangka dimaserasi dengan etanol $70 \%$, pelarut diuapkan dengan evaporator. Masing-masing ekstrak diuji aktivitas antioksidan dengan metode DPPH. Ekstrak buah ceremai $(E B C)$ dan kulit buah semangka (EKBS) dikombinasi ratio 1:1, 2:1 dan 1:2 dan dikembangkan formula serum wajah berdasarkan hasil kombinasi dengan aktivitas antioksidan terbaik. Ratio EBC dan EKBS (2:1) memberikan nilai IC50 terbaik yaitu sebesar 75,44 ppm. Serum F1 mengandung 0,76 g EBC dan 0,5 g EKBS sedangkan F2 adalah dua kali dari F1, komponen formula terdiri dari Xhantan Gum, Buthilen Glikol, Methylparaben dan Aquadest. Aktivitas antioksidan serum F2 memilki aktivitas terbaik dibandingkan serum F1 dengan nilai IC50 sebesar 326,71 ppm lebih baik dibandingkan dengan kontrol positif yaitu produk serum Vitamin C yang memiliki nilai IC50 816,65 ppm. Serum wajah F1 dan F2 berwarna coklat transparan, dengan aroma khas, $\mathrm{pH}$ serum F1dan F2 belum memenuhi standar SNI masing-masing sebesar 3,9 dan 3,7. Kedua formula serum memiliki kestabilan penyimpanan selama 3 bulan pada suhu 25oC dan 40 C. F2 menunjukkan adanya iritasi ringan pada kulit kelinci hal ini dipengaruhi oleh $\mathrm{pH}$ formula serum yang asam.
\end{abstract}

Kata kunci: Citrulus lanatus, DPPH, Serum, Phyllantus acidus

\section{Pendahuluan}

Kulit merupakan perlindungan paling luar dari tubuh dan jaringan kulit menjadi peran utama dalam pertahanan radiasi ultraviolet (1). Paparan radiasi UV merupakan penyebab utama stres oksidatif pada kulit sehingga menjadi faktor penyebab terjadinya masalah kulit seperti pembentukan keriput dan kanker (2).

Salah satu cara pencegahan kerusakan kulit akibat stres oksidatif yaitu dengan melakukan perawatan kulit melalui penggunaan kosmetik yang mengandung antioksidan seperti lotion dan serum. 
Serum merupakan sediaan kosmetik yang memiliki konsentrat tinggi dengan kemampuan penetrasi lebih dalam untuk menghantarkan bahan aktif ke dalam kulit (3). Senyawa fenolik dan flavonoid adalah golongan metabolit sekunder yang populer digunakan sebagai antioksidan(4).

Buah ceremai (Phyllantus acidus) diidentifikasi mengandung senyawa, kuarcetin, pylantusol $A$, pylantusol $B$, asam sinamat, asam sitrat, asam askorbat dan asam galat (5). Buah Phyllantus acidus memiliki total fenolik sebesar $204,75 \mathrm{mg} / \mathrm{g}$ dan kandungan asam askorbat sebesar 102,58 mg/g (6). Ekstrak metanol buah Phyllantus acidus menunjukkan aktivitas antioksidan tinggi dengan nilai IC50 sebesar 16 ppm (7). Buah Phyllantus acidus diidentifikasi mengandung senyawa asam glikolat sebesar $27,77 \%$ dan asam sitrat sebesar $39,81 \%$ (8). Jus kulit Citrullus lanatus mengandung fenolat sebesar 18,702 mg/g dan antioksidan dengan nilai IC50 sebesar 214,369 ppm(9). Kulit buah Citrullus lanatus mengandung retinol, tiamin, niacin dan asam askorbat (10). Pada penelitian ini dilakukan pengembangan formula serum wajah antioksidan dari kombinasi ekstrak buah ceremai dan kulit buah semangka.

\section{Metode}

Alat

Alat yang digunakan dalam penelitian ini yaitu gelas laboratorium (Pyrex, Indonesia) spektrofotometer UV-vis (Shimadzu), viscometer (Brookfiled, USA), vaccum rotary evaporator (IKA RV 10, Germany), stirrer (Thermo, Korea), dehidrator (Kris).

\section{Bahan}

Buah cermai (Phyllantus acidus) dan kulit buah semangka (Citrullus lanatus) diperoleh dari kabupaten Pandeglang, Banten. DPPH (Sigma aldrich), xhantan gum (PT. Sheva Mutiara Jaya, Bandung), buthylen glikol (PT. Sheva Mutiara Jaya, Bandung) methylparaben (PT. Sheva Mutiara Jaya Bandung), aquades, etanol (PT. Palapa Muda Perkasa, Jakarta), metanol (PT. Palapa Muda Perkasa, Jakarta), kelinci albino newzealand (PT.Dunia Kaca, Tawamangu)

\section{Prosedur Rinci}

1. Pengumpulan Bahan dan Determinasi Tanaman

Bagian tanaman buah ceremai dan kulit buah semangka dideterminasi di Pusat Penelitian Tumbuhan dan Kebun Raya LIPI Bogor. Buah ceremai dan kulit buah semangka dibuat simplisia dengan cara sampel dikeringkan menggunakan alat dehidrator pada suhu $40 \circ \mathrm{C}$.

2. Prosedur Pembuatan Ekstrak

Sampel dimaserasi dengan pelarut etanol $70 \%$ selama $3 \times 24$ jam (11) maserat dipekatkan dengan vaccum rotary evaporator. Ekstrak dihitung rendemennya 
3. Uji Aktivitas Antioksidan

Pengujian aktivitas antioksidan dilakukan mengikuti metode Pogaga (2020) dengan modifikasi (12). EBC dan EKBS, kombinasi EBC dan EKBS ratio perbandingan 1:1, 2:1, dan 1:2 dibuat deret konsentrasi $(50,100,150,200$ dan 250 ppm).Vitamin $C$ sebagai kontrol positif. Konsenterasi serum F0, F1, F2 (40,80,160,320 dan 640 ppm) sedangkan serum komersial sebagai kontrol positif sebesar $(62,5 ; 125 ; 250 ; 500$ ppm). Larutan uji dipipet 2,4 $\mathrm{mL}$, dan dimasukan dalam tabung reaksi, ditambahkan DPPH $0,5 \mathrm{mM}$ sebanyak $0,6 \mathrm{~mL}$, diinkubasi pada ruang gelap selama 30 menit. Absorbansi masing-masing sampel diukur pada panjang gelombang maksimum pada penelitian ini adalah $515 \mathrm{~nm}$, karena merupakan panjang gelombang yang memberikan serapan maksimum pada DPPH. Nilai IC50 dihitung berdasarkan nilai \% inhibisi pada masing-masing sampel dan penentuan regresi liniernya.

\section{Formula Serum Antioksidan}

Formula serum wajah antioksidan dapat dilihat pada (Tabel 1). Formula kombinasi dibuat menjadi 2:1 berdasarkan hasil aktivitas antioksidan masing-masing ekstrak. Jumlah zat aktif adalah 50 kali lipat untuk (F1) dan 100 kali lipat untuk (F2) dari nilai IC50 Antioksidan.

yang merupakan salah satu polimer golongan poliakrilat, dipilih sebagai pengental dan emulgator. Dari hasil penelitian ini diharapkan diperoleh formula krim dengan kandungan ekstrak daun kapuk yang efektif mengatasi jerawat dan stabil dalam penyimpanan.

Tabel 1. Formula serum wajah antioksidan (13)

\begin{tabular}{ccccc}
\hline No & Bahan & \multicolumn{3}{c}{ Formula (\%) } \\
\cline { 3 - 5 } & & $\mathrm{F} 0$ & $\mathrm{~F} 1$ & $\mathrm{~F} 2$ \\
\hline 1 & Ekstrak Buah & - & 0,76 & 1,53 \\
Ceremai & & & \\
& $\begin{array}{c}\text { Ekstrak Kulit } \\
\text { Buah Semangka }\end{array}$ & - & 0,5 & 1 \\
& & & \\
3 & Gom Xhantan & 0,40 & 0,40 & 0,40 \\
4 & Methyl paraben & 0,3 & 0,3 & 0,3 \\
5 & Butilen Glikol & 10 & 10 & 10 \\
6 & Aquades ad & 100 & 100 & 100 \\
\hline
\end{tabular}

5. Pengujian Formula Serum

a. Uji Organoleptis

Uji organoleptik sediaan serum dilakukan dengan mengamati warna, bau, dan bentuk (14)

b. Uji viskositas

Sediaan dimasukkan ke dalam gelas piala kemudian spindel diturunkan hingga batas spindel tercelup ke dalam sediaan. Angka viskositas yang ditunjukkan oleh jarum merah dicatat, kemudian dikalikan dengan faktor koreksi pada tabel (15). 
c. Uji pH

Pengukuran $\mathrm{pH}$ formula diukur menggunakan $\mathrm{pH}$ meter dengan cara sampel disiapkan sebanyak $50 \mathrm{~mL}$ ke dalam gelas kimia. Elektroda $\mathrm{pH}$ meter dicelupkan pada serum dan hasil dibaca pada monitor (14)

d. Uji Daya Sebar

Masing-masing formula serum sebanyak $1 \mathrm{~mL}$ diletakan di atas cawan petri dan dibiarkan 1 menit, kemudian diberikan beba sebesar $50 \mathrm{~g}$ dan didiamkan kembali 1 menit hasil pengamatan diukur diameter sebarnya (12)

e. Uji Homogenitas

Masing-masing formula serum dioleskan pada sekeping kaca transparan, diratakan dan diamati apakah ada partikel atau tidak (16)

f. Uji Stabilitas

Stabilitas sediaan dievaluasi pada suhu $40 \mathrm{C} \pm 20 \mathrm{C}$, dan $250 \pm 20 \mathrm{C}$ selama 3 bulan. Stabilitas yang diamati meliputi organoleptis (warna, bau dan bentuk) visikositas, homogenitas, daya sebar dan $\mathrm{pH}(15)$

g. Uji Iritasi (17)

Kelinci albino jantan New Zealand berat sekitar $2 \mathrm{~kg}$. Hewan uji diaklimatisasi selama 7 hari, bulu kelinci daerah punggung dicukur seluas $10 \%$. Formula serum yang terdiri dari F0, F1 dan F2 dioleskan pada bagian punggung kelinci dan diamati setelah pengolesan pada durasi 24,48 dan 72 jam. Kaji etik untuk uji iritasi diperoleh dari Komisi Etik Penelitian Kesehatan

Universitas Muhammadiyah Prof. DR. HAMKA (KEPK-UHAMKA) nomor persetujuan etik No:02/22.03/0936

\section{Hasil}

Hasil pengumpulan bahan dan Determinasi tanaman

Berdasarkan hasil determinasi dengan Nomor B-1194/IPH.3./KS/X/2020 menyatakan spesies yang digunakan pada penelitian ini adalah Phyllanthus acidus dan Citrullus lanatus.

Hasil ekstraksi

Hasil ekstraksi buah ceremai dan kulit buah semangka dapat dilihat pada (Tabel 2)

Tabel 2. Hasil ekstraksi dan rendemen

\begin{tabular}{ccccc}
\hline Sampel & $\begin{array}{c}\text { Berat } \\
\text { sampel } \\
(\mathrm{g})\end{array}$ & Simplisia (g) & $\begin{array}{c}\text { Bobot } \\
\text { Ekstrak } \\
\text { kental }(\mathrm{g})\end{array}$ & Rendemen (\%) \\
\hline EBC & 17,600 & 1000 & 299,9 & 29,99 \\
EKBS & 25,500 & 1000 & 163,8 & 16,38 \\
\hline
\end{tabular}


Hasil uji aktivitas antioksidan

Data aktivitas antioksidan ekstrak tunggal, kombinasi dan formula serum pada (Gambar 1 dan 2)

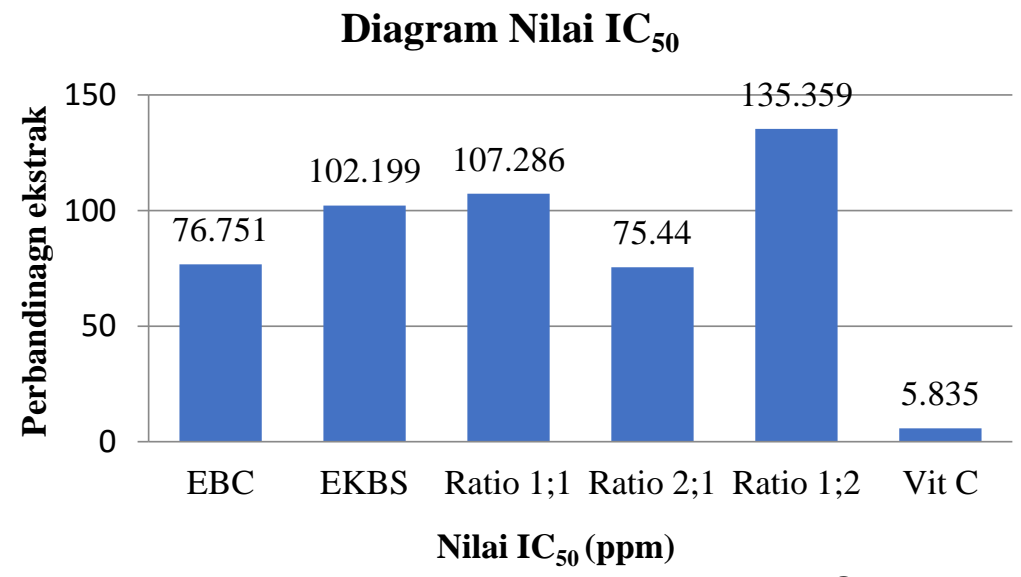

Gambar 1. Diagram perbandinagn nilai IC50 ekstrak

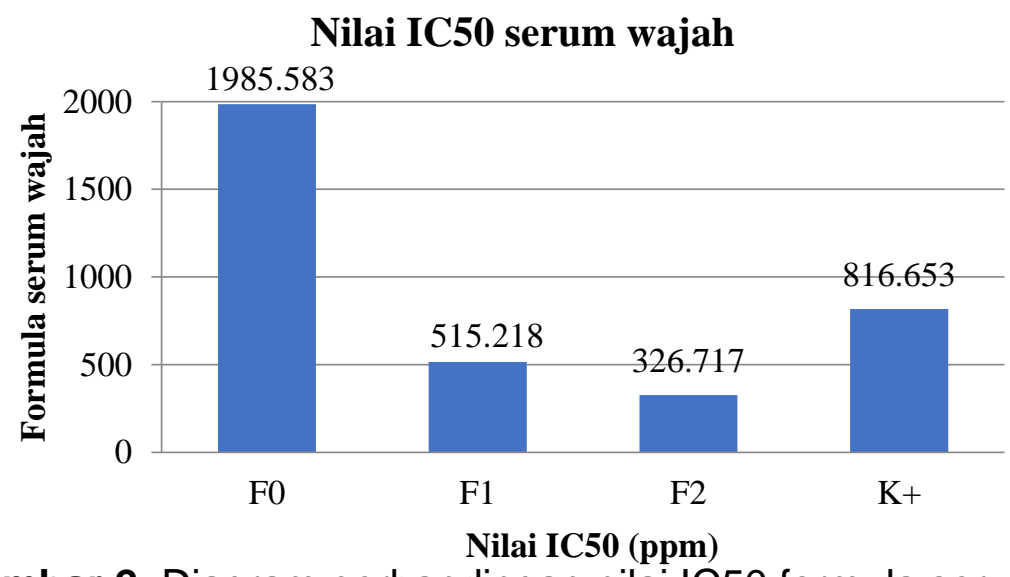

Gambar 2. Diagram perbandingan nilai IC50 formula serum wajah

Hasil pengujian formula serum wajah

Hasil pengamatan organoleptis formula serum memiliki warna coklat transparan, bau khas asam dan bentuk yang agak kental dan parameter fisik seperti pada Tabel 3.

Tabel 3. Hasil evaluasi formula serum

\begin{tabular}{ccccc}
\hline Sediaan & $\mathrm{pH}$ & $\begin{array}{c}\text { Visikositas } \\
\text { (mPas) }\end{array}$ & Homogenitas & $\begin{array}{c}\text { Daya } \\
\text { sebar }(\mathrm{cm})\end{array}$ \\
\hline F0 & 5,4 & 1480 & Homogen & 5 \\
F1 & 3,9 & 1280 & Homogen & 5,5 \\
F2 & 3,7 & 1080 & Homogen & 5,7 \\
\hline
\end{tabular}


Berdasarkan hasil evaluasi organoleptis formula F1 dan F2 pada suhu 4oC dan 25oC tetap stabil dan tidak mengalami perubahan pada $\mathrm{pH}$, viskositas, homogenitas dan daya sebar. Hasil pengamatan pH disajikan pada Gambar 3 , visikositas pada Gambar 4 dan daya sebar pada Gambar 5.

\section{Grafik stabilitas pH}

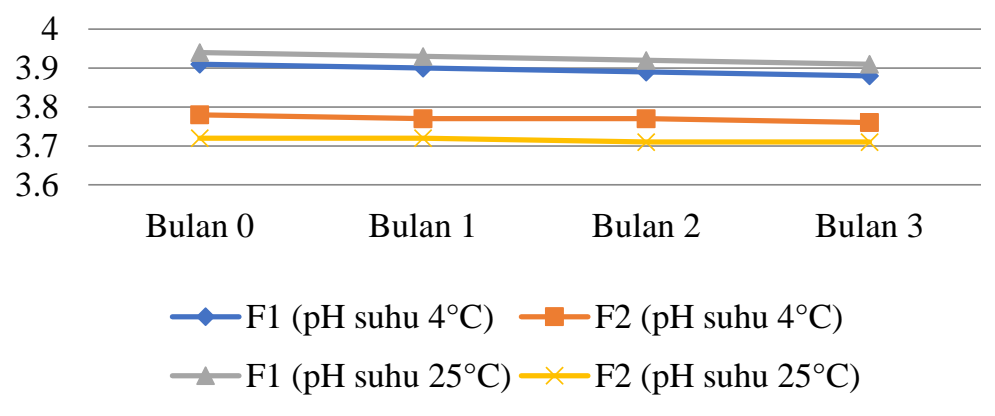

Gambar 3. Grafik stabilitas pH

\section{Grafik stabilitas visikositas}

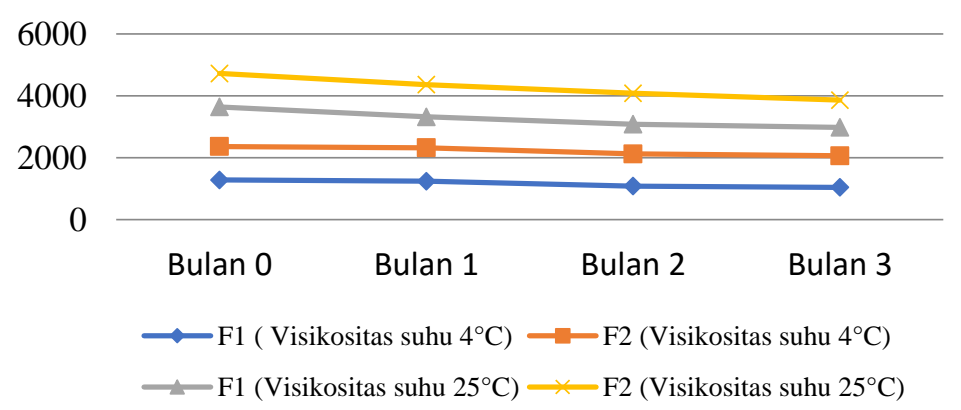

Gambar 4. Grafik stabilitas visikositas

Grafik daya sebar

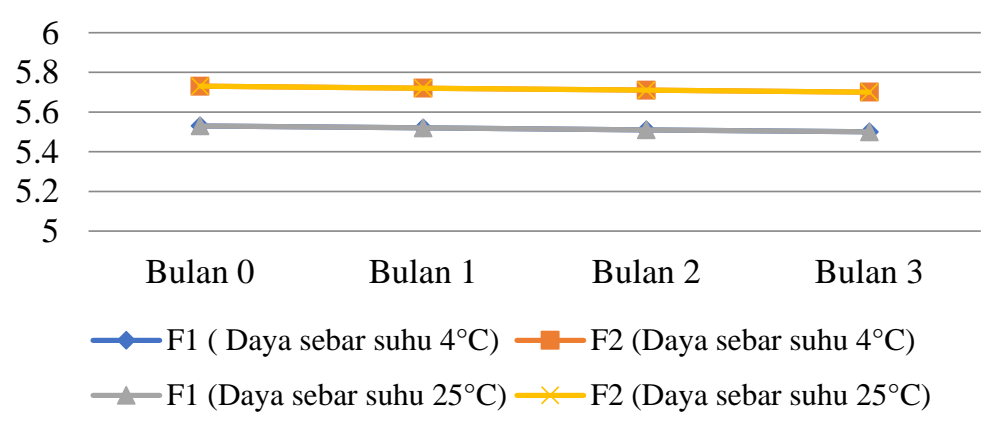

Gambar 5. Grafik daya sebar 
Hasil pengamatan uji iritasi

Hasil uji iritasi disajikan pada Tabel 4.

Tabel 4. Perhitungan indeks iritasi formula serum

\begin{tabular}{cccc}
\hline Kelompok uji & & Waktu \\
\cline { 3 - 4 } & 24 jam & 48 jam & 72 jam \\
\hline F0 & 0 & 0 & 0 \\
F1 & 0 & 0 & 0 \\
F2 & 1 & 1 & 1 \\
Indeks Iritasi F2 & \multicolumn{3}{c}{ F2 Iritasi sangat ringan } \\
Kesimpulan & \multicolumn{3}{c}{} \\
\hline
\end{tabular}

Rumus perhitungan (18) "

" "Indeks iritasai "= (A-B)/"C" " "

Keterangan

A

B

C

Skor 1

$0,5-1,9 \quad$ : Iritan ringan (slight)

: Jumlah skor eritema dan udema seluruh titik pengamatan sampel pada jam ke 24, 48 dan 72 dibagi jumlah pengamatan : Jumlah skor eritema dan udema seluruh titik pengamatan kontrol pada jam ke 24, 48, dan 72

: Jumlah hewan

\section{Pembahasan}

Simplisia dimaserasi dengan menggunakan etanol $70 \%$ karena lebih polar sehingga diharapkan dapat menarik senyawa yang bersifat polar (19). Persen rendemen EBC lebih tinggi dibandingkan EKBS (Tabel 2) menunjukan bahwa metabolit sekunder yang terdapat pada EBC lebih banyak tersari dalam pelarut dibandingkan EKBS. Junita dkk (2019) menyatakan ekstrak etanol $96 \%$ buah ceremai menghasilkan rendemen sebesar 7,717\% (21). Menurut Sumbayak (2018) ekstraksi kulit buah semangka menggunakan etanol 96\% menghasilkan rendemen sebesar $8 \%(23)$. Besar kecilnya hasil rendemen yang diperoleh dipengaruhi oleh keefektifan dalam proses ekstraksi. Faktor-faktor yang mempengaruhi hasil ekstraksi adalah waktu, suhu, pengadukan dan pelarut. Selain jenis pelarut, ukuran sampel juga mempengaruhi jumlah rendemen (24).

Vitamin C digunakan sebagai pembanding karena berfungsi sebagai antioksidan kuat. Secara spesifik suatu senyawa dikatakan antioksidan sangat kuat jika nilai IC50 kurang dari 50 ppm, kuat untuk IC50 bernilai 50-100 ppm, sedang jika IC50 151-200 ppm (25). Nilai IC50 menjadi parameter yang digunakan untuk menginterpretasikan hasil dari uji aktivitas antioksidan (17). Berdasarkan hasil pengukuran diperoleh nilai IC50 Vitamin C sebesar 5,83 ppm.

Hasil pengukuran antioksidan diketahui bahwa EBC memiliki aktivitas antioksidan lebih baik dibandingkan EKBS (Gambar 1). 
Bentuk kombinasi EBC dan EKBS ratio 2:1 digolongkan ke dalam aktivitas antioksidan kuat dengan IC50 75,44 ppm sedangkan ratio 1:1 (107,28 ppm) dan 1:2 (135,35 ppm) tergolong ke dalam aktivitas antioksidan sedang (Gambar 1). Pelarut yang berbeda mempengaruhi hasil pengujian aktivitas antioksidan pada buah ceremai dengan pelarut air nilai IC50 sebesar 26,06 ppm (26). Ekstrak metanol dengan nilai IC50 5,96 ppm (27). Sedangkan untuk ekstrak kulit buah semangka menghasilkan aktivitas antioksidan sebesar 14,729 ppm (28), jus kulit buah semangka menghasilkan nilai IC50 sebesar 214,369 ppm (9). Senyawa metabolit sekunder yang berpotensi mempunyai aktivitas antioksidan diantaranya yaitu alkaloid, fenolik dan flavonoid, senyawa-senyawa tersebut mendonorkan elektron bebas pada atom oksigen di dalam gugus hidroksil atau atom hidrogen yang dapat mereduksi reaktivitas senyawa radikal bebas menjadi stabil (29). Tan et al (2020) menyatakan bahwa buah ceremai memiliki total fenolik sebesar 204,75 $\mathrm{mg} / \mathrm{g}(7)$. Sedangkan jus kulit buah semangka menghasilkan senayawa fenolik sebesar $18,702 \mathrm{mg} / \mathrm{g}$ (9). Adanya perbedaan senyawa fenolik yang terkandung pada sampel dapat berpengaruh pada hasil aktivitas antioksidan, senyawa golongan fenolik memberikan pengaruh positif dalam aktivitas antioksidan. Semakin besar total fenolik suatu sampel maka diikuti dengan meningkatnya aktivitas antioksidan(30).

Pada kombinasi ekstrak (2:1) memberikan efek peningkatan terhadap aktivitas. Penggunaan kombinasi EBC dan EKBS secara bersamaan mempunyai efek sinergis dalam peningkatan aktivitas antioksidan. Jumlah senyawa metabolit sekunder yang berbeda pada masing-masing ekstrak mempengaruhi pada perbedaan nilai IC50 yang dihasilkan.

Formula serum wajah antioksidan menggunakan Xhantan gum sebagai pengental dan Buthylenglikol sebagai pelarut semua komponen dicampur sehingga membentuk gel serum, penambahan methylparaben pada formula berfungsi sebagai pengawet.

Berdasarkan hasil uji antioksidan serum wajah masuk dalam kategori lemah, F2 menghasilkan nilai IC50 lebih kecil dibandingkan F1, dan kontrol positif (Gambar 2). Hal ini berkaitan dengan aktivitas antioksidan ekstrak tunggal buah cermai dan kombinasi ratio 2:1 yang paling kuat meredam radikal bebas.

Sediaan serum wajah menunjukkan warna coklat transparan, agak kental, homogen dan bau khas asam. Warna coklat transparan disebabkan oleh ekstrak yang terkandung dan penggunaan xanthan gum. Sedangkan bau khas asam dipengaruhi oleh ekstrak ceremai yang memiliki aroma asam. Hasil pengamatan visikositas disajikan pada (Tabel 3) diperoleh visikositas cukup baik karena viskositas sediaan serum wajah berbasis gel berada pada rentang 800 - 3000 mPas. Daya sebar yang baik adalah memiliki diameter $5-7 \mathrm{~cm}$ (31). Hasil yang diperoleh daya sebar pada semua formula masuk pada rentang yang baik (Tabel 3). Kandungan zat aktif dalam sediaan serum mempengaruhi pH dimana $\mathrm{F} 1$ memiliki $\mathrm{pH}$ 3,9 sedangkan $\mathrm{F} 2$ memiliki $\mathrm{pH}$ yang lebih rendah yaitu 3,7 disebabkan oleh karakteristik dari ekstrak yang $\mathrm{pH}$ nya relatif bersifat asam sehingga formula serum belum sesuai dimana rentang $\mathrm{pH}$ sediaan topikal berdasarkan $\mathrm{SNI}$ yaitu 4,5-8 (SNI 16-4399-1996). 
Uji stabilitas berhubungan dengan kualitas sediaan dengan waktu penyimpanan. Hasil pengamatan stabilitas formula serum selama 3 bulan pada suhu $40 \mathrm{C}$ dan $250 \mathrm{C}$ disajikan pada Gambar 2,3 dan 4, tidak ada perubahan yang signifikan pada pH serum F1 dan F2 tetapi ada penurunan visikositas. Viskositas sediaan dipengaruhi oleh beberapa faktor seperti proses pencampuran, pemilihan bahan pengental dan ukuran partikel(32).

Tujuan uji iritasi adalah untuk menentukan adanya efek iritasi pada kulit serta untuk menilai dan mengevaluasi karakteristik suatu zat apabila terpapar pada kulit (33). Pengamatan dilakukan pada 24, 48 dan 72 jam setelah diberikan sediaan uji dengan cara mengamati reaksi kulit yang timbul dengan 2 parameter utama pengamatan, yaitu tingkat eritema dan udema yang timbul, kemudian hasil tersebut diberikan skor 0 sampai dengan 4, sesuai dengan tingkat keparahannya kemudian hasil dihitung skor indeks iritasinya (18). Berdasarkan data pengamatan F0 dan F1 tidak terjadi iritasi sedangkan $\mathrm{F} 2$ berdasarkan skor indeks iritasi sebesar 0,33 yang artinya mempunyai efek iritasi ringan hal ini dipengaruhi oleh $\mathrm{pH}$ formula serum yang cukup asam (18)

\section{Kesimpulan}

Formula serum wajah kombinasi ekstrak buah ceremai dan kulit buah semangka memiliki aktivitas antioksidan. Serum F2 memiliki aktivitas terbaik dibandingkan F1 dengan nilai IC50 sebesar 326,71 ppm dan lebih baik dibandingkan dengan kontrol positif produk serum vitamin C. Serum wajah F1 dan F2 stabil selama penyimpanan pada suhu $40 \mathrm{C}$ dan $250 \mathrm{C}$. Uji iritasi pada kulit kelinci menunjukkan adanya iritasi ringan pada F2.

\section{Daftar Pustaka}

1. Kim J, Kim YH, Bang S, Yoo H, Kim IK, Chang SE, et al. L-765,314 suppresses melanin synthesis by regulating tyrosinase activity. Molecules. 2019;24(4):1-13.

2. Sari W, Puspita, Berawi K, Nisa, Karima N. Managemen Topikal Anti- Aging pada Kulit Topical Anti-Aging Management of the Skin. Medula. 2019;9:237-43.

3. Thakre AD. Formulation and Development of De Pigment Serum Incorporating Fruits Extract. Int J Innov Sci Res Technol. 2017;2(12):330-82.

4. Dixit D, Reddy CRK. Non-targeted secondary metabolite profile study for deciphering the cosmeceutical potential of red marine macro alga Jania rubensAn LCMS based approach. Cosmetics. 2017;4(4):1-17.

5. Abd Ghafar SZ, Mediani A, Maulidiani M, Rudiyanto R, Mohd Ghazali H, Ramli NS, et al. Complementary NMR- and MS-based metabolomics approaches reveal the correlations of phytochemicals and biological activities in Phyllanthus acidus leaf extracts. Food Res. 2020;136(April):109312.

6. Suliaman, Shaida Fariza and Ooi LK. Antioxidant and a-Glucosidase Inhibitory sulaiman2014.pdf. Algriculture Food Chem. 2014; 
7. Tan SP, Tan ENY, Lim QY, Nafiah MA. Phyllanthus acidus (L.) Skeels: A review of its traditional uses, phytochemistry, and pharmacological properties. J Ethnopharmacol. 2020;253.

8. Indriatmoko D, Suryani N, Rudiana T, Kurniah M. Formulation and physical evaluation of facial cream preparations from Ceremai fruit juice (Phyllanthus acidus (I.) Skeels). Pharm Educ. 2021;21:87-92.

9. Ismayanti, Bahri S, Nurhaeni. Kajian Kadar Fenolat Dan Aktivitas Antioksidan Jus kulit Buah Semangka (Citrullus Lanatus). J Nat Sci. 2013;2(2):36-45.

10. Gladvin G, Sudhaakr G, Swathi V, Santhisri K V. Mineral and Vitamin Compositions Contents in Watermelon Peel (Rind). Int J Curr Microbiol Appl Sci. 2017;5(5):129-33.

11. Maryam F, Taebe B, Toding DP. Pengukuran Parameter Spesifik Dan Non Spesifik Ekstrak Etanol Daun Matoa (Pometia pinnata J.R \& G.Forst). J Mandala Pharmacon Indones. 2020;6(01):1-12.

12. Pogaga E, Yamlean PVY, Lebang JS. Formulasi Dan Uji Aktivitas

Antioksidan Daun Murberry ( Morus alba L .) Menggunakan Metode DPPH (1,1Diphenyl-2-Picrylhydrazyl) Formulation And Antioksidan Activty Test Of Mulberry Leaf (Morus alba L.) Ethanol Extract Cream Using. Pharmacon. 2020;9:349-56.

13. Goeswin Agoes. Sediaan Kosmetik (SFI-9). ITB Bandung; 2015.

14. Ojha S, Chadha H, Aggarwal B. Formulation and Evaluation Of Face Serum Containing Bee. World J Pharm Res. 2019;8(February):1100-5.

15. Hasrawati A, Hardianti H, Qama A, Wais M. Pengembangan Ekstrak Etanol Limbah Biji Pepaya (Carica papaya L.) Sebagai Serum Antijerawat. J Fitofarmaka Indones. 2020;7(1):1-8.

16. Noer HBM, Sundari. Formulasi hand and body lotion ekstrak kulit buah naga putih (Hylocereus undatus ) dan uji kestabilan fisiknya. Kesehatan. 2016;XI(1):101-14.

17. Adhi Pradana D, Hernawan Nugroho B. Uji Stabilitas Dan Uji Iritasi Primer Sediaan Kosmetik Mikroemulsi Vitamin C Palmitat (Ascorbyl Pamitate). J IIm Farm. 2016;12(1):10-21.

18. Zainur Rahman Hakim, Kharisma Ayu Purbarini TTT. Uji Iritasi Akut Ddermal Pada Hewan Uji Kelinci Albino Terhadap Sediaan Body Lotion Ekstrak Kulit Biji Pinang (Areca Catechu L.). Farmaka. 2018;16(1):213-21.

19. Mutmainnah N, Chadijah S, Qaddafi M. Penentuan Suhu Dan Waktu Optimum Penyedyhan Batang Teh Hijau (Camelia Sinensis L.) Terhadap Kandungan Antioksidan Kafein,Tanin Dan Katekin. Lantanida J. 2018;6(1):1.

20. Sari AK, Ayati R. Penentuan Aktivitas Antioksidan Ekstrak Etanol Daun Jeruk Purut (Citrus hystrix D.C) dengan Metode DPPH (1,1-diphenyl-2picrylhydrazyl). J Curr Pharm Sci. 2018;1(2):69-74.

21. Junita M, Purwanti L, Syafnir L. Uji Aktivitas Tabir Surya Ekstrak Etanol dan Fraksi Buah Cereme (Phyllanthus acidus (L.) Skeels dengan Metode Spektrofotometri UV- Sinar Tampak. 2015; 
22. Muthia R, Amalia, Maulana A, Puteri MR, Rizaldi G, Amadia S. Uji Aktivitas In Vivo Ekstrak Etanol Kulit Buah Semangka (Citrulus lanatus L.) Sebagai Diuretik Dengan Pembanding Furosemid. Borneo $J$ Pharmascientech. 2017;01(01):67-75.

23. Sumbayak AR, Diana VE. Formulasi Hand Body Lotion Ekstrak Etanol Kulit Buah Semangka (Citrillus vulgaris) untuk Pelembab Kulit. J Dunia Farm. 2019;2(2):70-6.

24. Jagung T, Sineke FU, Suryanto E, Sudewi S. Penentuan Kandungan Fenolik Dan Sun Protection Factor (SPF) Dari Ekstrak Etanol Dari Beberapa Tongkol Jagung (Zea mays L.). Pharmacon. 2016;5(1):275-83.

25. Andriani D, Murtisiwi L. Uji Aktivitas Antioksidan Ekstrak Etanol 70\% Bunga Telang (Clitoria ternatea L) dari Daerah Sleman dengan Metode DPPH. Pharmacon J Farm Indones. 2020;17(1):70-6.

26. D Andrianto1 WW and MB. Antioxidant and Cytotoxic Activity of Phyllanthus acidus Fruit Extracts To. IOP Conf Ser Earth Environ Sci Pap.

2017;1-5.

27. Foyzun T, Aktar K, Uddin MA. Evaluation of antioxidant, cytotoxic and antimicrobial activity of Phyllanthus acidus. Int $\mathrm{J}$ Pharmacogn Phytochem Res. 2016;8(11):1751-8.

28. Mariani S, Rahman N, Supriadi S. Uji Aktivitas Antioksidan Ekstrak Buah Semangka (Citrullus lanatus). J Akad Kim. 2018;7(3):107.

29. Meliani Sari, Rani Nareza Ulfa, Mauritz Pandapotan Marpaung P. Penentuan Aktivitas Antioksidan dan Kandungan Flavonoid Total Ekstrak Daun Papasan (Coccinia grandis L.) Berdasarkan Perbedaan Pelarut Polar. kovalen J Ris Kim. 2021;7(1):30-41.

30. Rudiana T, Indriatmoko DD, Km RL, Pandeglang S, Indonesia B, Km RL, et al. Aktivitas Antioksidan Kombinasi Ekstrak Etanil Daun Salam( Syzygium polyanthum ) Dan Daun Kelor. 2020;25(1):20-2.

31. Mardhiani YD, Yulianti H, Azhary DP, Rusdiana T. Formulasi Dan Stabilitas Sediaan Serum Dari Ekstrak Kopi Hijau (Coffea canephora var. Robusta)Sebai Antioksidan. Indones Nat Res Pharm J Univ 17 Agustus 1945 Jakarta. 2018;2(2):19-33.

32. Septiyanti M, Liana L, Sutriningsih, Kumayanjati B, Meliana Y. Formulation and evaluation of serum from red, brown and green algae extract for anti-aging base material. AIP Conf Proc. 2019;2175(November).

33. RI BPO dan M. Peraturan Badan pengawas Obat dan Makanan Republik Indonesia. Farmakovigilans. 2014;53:1689-9 